ENTREPRENEURSHIP AND SUSTAINABILITY ISSUES

ISSN 2345-0282 (online) http://jssidoi.org/jesi/

2021 Volume 8 Number 3 (March)

http://doi.org/10.9770/jesi.2021.8.3(19)
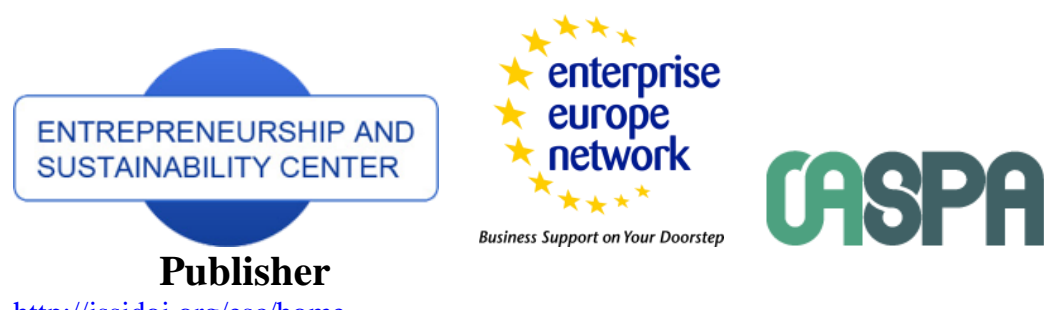

http://jssidoi.org/esc/home

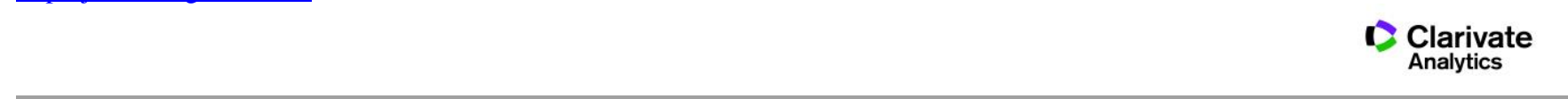

\title{
ASSESSMENT OF THE SITUATION CONCERNING PSYCHOLOGICAL SUPPORT TO THE PUBLIC AND BUSINESS IN THE EXTREME CONDITIONS: CASE OF COVID-19
}

\author{
Tomas Davulis ${ }^{1}$, Ligita Gasparèniené ${ }^{2}$, Evaldas Raistenskis ${ }^{3}$ \\ 1,2, 3 Vilnius University, Law faculty, address: Sauletekio av. 9, Vilnius, Lithuania \\ E-mails: ${ }^{1}$ tomas.davulis@tf.vu.lt; ${ }^{2}$ ligita.gaspareniene@tf.vu.lt; ${ }^{3}$ evaldas.raistenskis@tf.vu.lt \\ Received 18 September 2020; accepted 20 December 2020; published 30 March 2021
}

\begin{abstract}
Restrictions on personal freedom, work or business loss, increasing financial tensions, limited communication with close people, friction between the people isolated within the household, uncertainty about the future, especially in the context of conflicting information coming from authorities, medical representatives and media reports, and other Covid-19 pandemic related factors are likely to substantially raise the spread of emotional distress and the risk of mental disorders and illnesses. In the context of such unprecedentedly high risks for society to develop mental disorders, it is purposeful to research the aspects of the provision of psychological support to the public in extreme conditions. Given the high number of stressors, an extremely high degree of uncertainty and a wide range of vulnerable social groups (entrepreneurs, pensions, family with children and etc.), the growing tensions in society necessitate the expansion of the scope of psychological support provided to the public. The main purpose of this research is to assess the situation concerning psychological support to the public in the extreme conditions at the national level.
\end{abstract}

Keywords: COVID-19; Corona virus; Psychological support; extreme conditions; business, society

Reference to this paper should be made as follows: Davulis, T., Gasparènienė, L., Raistenskis, E. 2021. Assessment of the situation concerning psychological support to the public and business in the extreme conditions: case of Covid-19. Entrepreneurship and Sustainability Issues, 8(3), 308-323. http://doi.org/10.9770/jesi.2021.8.3(19)

JEL Classifications: I15, I18

\section{Introduction}

Every crisis has a major impact on entrepreneurs and the businesses they run, regardless of what disaster (natural, human behaviour or economic) it was caused by. At the end of December 2019, the coronavirus (COVID-19) outbreak started in Wuhan, China, and spread around the world so quickly that in March 2020 the World Health Organisation declared COVID-19 the global pandemic. Lithuania was no exception. During the first and second waves, social life came to a standstill, businesses were forced to close down or move to cyberspace. Unfortunately, not all entrepreneurs, especially those working under business licences, like massage masters, small traders, etc., had to temporarily suspend their activities, severely restrict them or become unemployed. The stressful period people are undergoing can have negative effects on their mental health. For this reason, 


\section{ENTREPRENEURSHIP AND SUSTAINABILITY ISSUES}

ISSN 2345-0282 (online) http://jssidoi.org/jesi/

2021 Volume 8 Number 3 (March)

http://doi.org/10.9770/jesi.2021.8.3(19)

Make your research more visible, join the Twitter account of ENTREPRENEURSHIP AND SUSTAINABILITY ISSUES: @Entrepr69728810

comprehensive research that would assess population's psychological well-being at the national level is extremely relevant.

Restrictions on personal freedom, work or business loss, increasing financial tensions, limited communication with close people, friction between the people isolated within the household, uncertainty about the future, especially in the context of conflicting information coming from authorities, medical representatives and media reports, and other Covid-19 pandemic related factors are likely to substantially raise the spread of emotional distress and the risk of mental disorders and illnesses.

Some social groups are particularly vulnerable to the adverse effects of the Covid-19 pandemic. This applies to people infected with coronavirus, families with people with chronic illnesses, the elderly with a weakened immune system, people with pre-existing medical and/or mental problems, medical staff working in 'hot spots', entrepreneurs, self-employed, etc. Given the high number of stressors, an extremely high degree of uncertainty and a wide range of vulnerable social groups, the growing tensions in society necessitate the expansion of the scope of psychological support provided to the public.

In the context of such unprecedentedly high risks for society and business to develop mental disorders, it is purposeful to research the aspects of the provision of psychological support to the public and business in extreme conditions. Previous studies mainly focused on the target psychological intervention measures (Orru et al., 2020; Pfefferbaum and North, 2020; Zhou, 2020; Connolly et al., 2020, Besenyő and Kármán, 2020 etc.), assisting healthcare professionals (Vizheh et al., 2020; Inchausti et al., 2020; Chen et al., 2020, etc.), profiling support providing psychotherapists (Humer et al., 2020) and other issues (Koushik 2020; Marazziti et al., 2020)., but provision of psychological support to the public in extreme conditions has hardly been researched following a systematic approach.

The main purpose of this research is to assess the situation concerning psychological support to the public in the extreme conditions at the national level. The defined purpose was detailed into the following objectives: 1) to review the main components of a system of psychological support to the public in the extreme conditions; 2) to select and substantiate the methods of the research; 3) based on the results of the empirical research, to provide assessment of the current situation concerning psychological support to the public in the extreme conditions at the national level. The research methods include comparative and systematic literature analysis, simple random survey of professional psychologists.

\section{Review of the main components of a system of psychological support to the public in the extreme conditions}

To prevent the psychopathological changes in society's mental health and to respond rapidly to their increased risk and predicted evolution in the forms of maladaptive behaviours and a broader range of emotional disorders, appropriate psychological support measures, in scientific literature also referred to as psychological intervention measures, must be undertaken. As it was noted by Duan and Zhu (2020), psychological intervention in the current emergency conditions must be dynamic and flexible so that the measures undertaken can be promptly adjusted to the rapidly changing environment, requirements and constraints. According to Mohammed et al. (2015), in the system of psychological support to the public, the professionals of mental health care (clinical psychologists, psychotherapists and psychological intervention specialists) need to actively cooperate with other medical professionals and even public information providers. It means not only ensuring that the public has access to mental health care services and resources, but also raising public awareness of the importance of mental health 
ENTREPRENEURSHIP AND SUSTAINABILITY ISSUES

ISSN 2345-0282 (online) http://jssidoi.org/jesi/

2021 Volume 8 Number 3 (March)

http://doi.org/10.9770/jesi.2021.8.3(19)

Make your research more visible, join the Twitter account of ENTREPRENEURSHIP AND SUSTAINABILITY ISSUES: @Entrepr69728810

and the risks it is exposed to under the conditions of the Covid-19 pandemic. When planning how the entire healthcare system is going to function, it is essential to focus not only on the issues related to physical treatment, but also on dealing with the destructive psychological impacts of the pandemic (Inchausti et al., 2020).

When forming the systems of psychological support to the public, direct and remote channels, through which the target psychological intervention measures are implemented by applying a variety of methods, are invoked. Based on scientific literature analysis, the main components of a system of psychological support to the public are reviewed in Table 1.

Table 1. The main components of a system of psychological support to the public

\begin{tabular}{|c|c|c|c|}
\hline Support channel & Support methods & $\begin{array}{r}\text { Support measures } \\
\end{array}$ & Author(s), year \\
\hline \multirow{6}{*}{$\begin{array}{l}\text { Direct channel } \\
\text { (onsite) }\end{array}$} & Organisational methods & $\begin{array}{l}\text { First level: establishment of leading groups of } \\
\text { professionals, development of guidelines, } \\
\text { working programs and manuals, arrangement of } \\
\text { pre-training workshops; second level: } \\
\text { establishment of a psychological intervention } \\
\text { team; formation of functional sub-groups; third } \\
\text { level: feedback mechanisms }\end{array}$ & $\begin{array}{l}\text { Dong and Bouey, 2020; He et } \\
\text { al., } 2020\end{array}$ \\
\hline & Administrative methods & $\begin{array}{l}\text { Monitoring reactions and activities, task } \\
\text { redistribution, schedule adjusting, modification } \\
\text { of expectations }\end{array}$ & Pfefferbaum and North, 2020 \\
\hline & Instructing, special training & $\begin{array}{l}\text { Management of anxiety, fear of contagion, } \\
\text { prevention of burnout }\end{array}$ & $\begin{array}{l}\text { Inchausti et al., 2020; Chen et } \\
\text { al., 2020; Pfefferbaum and } \\
\text { North, } 2020\end{array}$ \\
\hline & $\begin{array}{l}\text { Engagement } \begin{array}{r}\text { of } \\
\text { emotionally vulnerable } \\
\text { population groups }\end{array} \\
\end{array}$ & $\begin{array}{l}\text { Support to emotionally vulnerable individuals, } \\
\text { monitoring patients with mental health disorder } \\
\text { symptoms }\end{array}$ & Inchausti et al., 2020 \\
\hline & Treatment with drugs & $\begin{array}{l}\text { Drugs for increased anxiety, insomnia, } \\
\text { hypochondriasis, post-traumatic stress disorder, } \\
\text { etc. }\end{array}$ & $\begin{array}{l}\text { National Institute for Health } \\
\text { and Care Excellence (NICE), } \\
\text { 2018; Inchausti et al., 2020 }\end{array}$ \\
\hline & $\begin{array}{l}\text { Involvement of a } \\
\text { psychologist/psychiatrist in } \\
\text { an organisation }\end{array}$ & $\begin{array}{l}\text { Establishment of a full-time or part-time } \\
\text { psychologist position, consultations of an } \\
\text { arriving psychologist/psychiatrist }\end{array}$ & Jiang et al., 2020 \\
\hline \multirow{3}{*}{$\begin{array}{l}\text { Remote channel } \\
\text { (remote } \\
\text { psychotherapy, } \\
\text { telemedicine) }\end{array}$} & $\begin{array}{l}\text { Dissemination } \\
\text { information }\end{array}$ & $\begin{array}{l}\text { Dissemination of information through mass } \\
\text { media (TV, radio, etc.) on how to behave in the } \\
\text { current circumstances, expert recommendations } \\
\text { for stress relief, reduction of negative } \\
\text { information flows }\end{array}$ & $\begin{array}{l}\text { Zhou, 2020; Humer et al., } \\
2020\end{array}$ \\
\hline & Telephone hotlines & $\begin{array}{l}\text { Counselling by phone, health care emergency } \\
\text { responders }\end{array}$ & $\begin{array}{l}\text { Zhou, 2020; } \\
\text { Humer et al., 2020; Orru et al., } \\
2020 ; \quad \text { World Health } \\
\text { Organisation, } 2020\end{array}$ \\
\hline & Internet & $\begin{array}{l}\text { Online counselling services, online } \\
\text { questionnaires for diagnosing patients' metal } \\
\text { health condition, patient-tailored treatment, } \\
\text { training and education through communication } \\
\text { platforms }\end{array}$ & $\begin{array}{l}\text { Jiang et al., 2020; Humer et } \\
\text { al., 2020; Vizheh et al., 2020; } \\
\text { Orru et al., 2020; Xiao et al., } \\
2020\end{array}$ \\
\hline
\end{tabular}

The information in Table 1 shows that two main channels for implementation of particular psychological intervention measures are direct and remote. The direct channel represents the methods and measures based on a direct contact with a subject. This channel serves as a medium for application of organisational and administrative 


\section{ENTREPRENEURSHIP AND SUSTAINABILITY ISSUES}

ISSN 2345-0282 (online) http://jssidoi.org/jesi/

2021 Volume 8 Number 3 (March)

http://doi.org/10.9770/jesi.2021.8.3(19)

Make your research more visible, join the Twitter account of ENTREPRENEURSHIP AND SUSTAINABILITY ISSUES: @Entrepr69728810

methods, instructing and special training, engagement of emotionally vulnerable population groups, treatment with drugs and involvement of a psychologist/psychiatrist in an organisation.

By applying organisational methods, first of all, a leading group of competent experts is formed at the level of the national government. This group manages the intervention and is responsible for the overall planning and implementation of the intervention measures. For instance, when developing a model of public psychological resilience to the Covid-19 pandemic in China, the Chinese government issued the order to form a leading panel of experts at the Chengdu Mental Health Centre; following the "Guideline for the Emergent Psychological Crisis Intervention during the Novel Coronavirus Pneumonia Pandemic", approved by the National Health Commission of China on 25 January 2020, the above-mentioned panel of experts developed working programs for targeted psychological intervention (He et al., 2020). The working programs were implemented in several steps. First, on the basis of the working programs, work manuals were developed and pre-training workshops for the staff under the programs were arranged. Second, a psychological intervention team consisting of mental health professionals (psychologists, psychotherapists, psychiatrists, psychiatric nurses) was established. The members of the team of professionals were divided into 4 functional sub-groups: 1) live media group; 2) hotline consultation group; 3) online video intervention group; 4) on-site intervention group (He et al., 2020). Finally, to ensure that the psychological intervention measures are applied in a targeted and timely manner, feedback mechanisms were developed within the organisational system, i.e. the functional sub-groups were required to report regularly to the leading group. The significance of organisational measures, and in particular the importance of the role of the national leading group and functional sub-groups, is also supported by Dong and Bouey (2020). According to the authors, namely organisational mechanisms help to ensure the necessary coordination and financing of the intervention, while the intervention plan helps to select target measures for the intervention to different social groups.

Pfefferbaum and North (2020) note that to maintain the psychological health of the public, systemic measures need to be undertaken to reduce both the stress experienced by individuals and the stress associated with performing major operations. To accomplish these objectives, the authors propose administrative methods that can be invoked for application of such stress reduction measures as monitoring reactions and activities, task redistribution, schedule adjusting and modification of expectations. These measures are mainly proposed at the level of organisations: organisations should appoint persons to monitor both individual reactions of employees to emerging stressors and reactions to assigned tasks; when workloads are increasing, work tasks need to be redistributed and staff work schedules (especially in medical facilities) need to be adjusted. When working in extreme conditions, minimisation of the expectations previously set for employees can also contribute to stress reduction.

Inchausti et al. (2020) highlight the significance of instructing and special training methods. Having researched the issues of assisting frontline health professionals and Covid-19 diagnosed patients, the authors note that the special training provided to the former can substantially help them learn to manage their emotional reactions to work situations. When providing special training, frontline health professionals have to be trained to manage anxiety and fear of contagion, prevent burnout. The opinion that the above-mentioned measures can significantly contribute to psychological resilience of medical staff is also supported by Chen et al. (2020). What concerns the assistance to most emotionally vulnerable population groups, Inchausti et al. (2020) recommend the "support to the individuals undergoing COVID-19 treatment or preventative quarantine" (p. 3). Monitoring patients with mental health disorder symptoms is also advised. 


\section{ENTREPRENEURSHIP AND SUSTAINABILITY ISSUES}

ISSN 2345-0282 (online) http://jssidoi.org/jesi/

2021 Volume 8 Number 3 (March)

http://doi.org/10.9770/jesi.2021.8.3(19)

Make your research more visible, join the Twitter account of ENTREPRENEURSHIP AND SUSTAINABILITY ISSUES: @Entrepr69728810

In case patients show such symptoms as increased anxiety, insomnia, hypochondriasis, post-traumatic stress disorder, etc., the measures of intervention can include drug prescription on condition that the use of drugs is as minimal as possible (National Institute for Health and Care Excellence (NICE), 2018).

Jiang et al. (2020) emphasise the importance of involvement of a psychologist/psychiatrist in an organisation (onsite psychotherapy). This is particularly the case for medical institutions, but may also apply to other organisations or sectors (e.g. sectors and/or businesses that have already lost or are at high risk of losing staff, companies on the verge of bankruptcy, etc.). According to the authors, onsite services can substantially help medical staff, patients and other affected people to overcome the psychological difficulties they are facing. Involvement of a psychologist/psychiatrist can be arranged by establishing a permanent work place or a professional can regularly arrive to provide onsite counselling.

Since traditional formats of psychotherapeutic care, i.e. the formats based on a direct contact between a patient and a psychologist/psychiatrist, pose a risk of infection transmission between the persons in contact under the conditions of the Covid-19 pandemic, one of the most obvious solutions is providing mental health care services remotely. (Humer et al., 2020).

In this context, the importance of disseminating information to the public is emphasised. Mass media channels (e.g. television, radio, internet, etc.) can be invoked to disseminate the information on what personal safety and hygiene practices can help one protect against infection, and thus contribute to reducing the overall level of social anxiety (Zhou, 2020). Humer et al. (2020) state that information can help to normalize the reaction of different social groups to stress, if the public information channels provide the information on what people can and/or must do in the current circumstances so that the situation can be managed. Specialist recommendations for stress relief (e.g. restructuring individual activities, adherence to normal routines, etc.) may also be provided. On the other hand, because the news and statistics related to the spread of the Covid-19 infection can raise public anxiety and panic, the flows of the negative information through public information channels are proposed to be limited. Zhou (2020) describes the positive effects of the psychological assistance telephone hotlines. 24-hour working free psychological assistance hotlines in Sichuan province, opened from February 6, enabled citizens to relieve their negative emotions. Because citizens with non-critical problems are strongly recommended not to visit treatment facilities during the Covid-19 pandemic outbreak, the psychological assistance hotlines serve as a measure that significantly contributes to maintaining public mental health. As it was noted by the World Health Organisation (2020), telephone hotlines help to establish a direct link between at-risk citizens and emergency responders on the basis of trust. From a broader perspective, hotlines serve not only as a risk communication and community engagement channel (RCCE) that helps save lives and minimize adverse consequences, but also as a feedback channel that minimizes the extreme situation related rumours and misunderstandings.

Remote psychotherapy can also be practised through the Internet (online). Xiao et al. (2020) and Orru et al. (2020) in their studies revealed that universities and institutes operating in different parts of the world activate provision of online counselling services, for this purpose invoking social media platforms and e-mails. Orru et al. (2020) mention online questionnaires distributed by Chinese authorities to assess a person's mental condition. Questionnaire-based data help to allocate resources and apply patient-tailored treatment. According to Humer et al. (2020), in a similar way patients can be surveyed when researching the impact of Covid-19 related stressors (e.g. contacting an infected person, loss of a loved one, physical distance, etc.), secondary stressors (e.g. economic difficulties), mental factors (depression, sensitivity, domestic violence, etc.). Andersson's (2016) research revealed that remote psychotherapy provides good results compared to the methods of the traditional contact psychotherapy. Shulman et al. (2017), Thomas et al. (2018) and other authors note that patients tend to have 


\section{ENTREPRENEURSHIP AND SUSTAINABILITY ISSUES}

ISSN 2345-0282 (online) http://jssidoi.org/jesi/

2021 Volume 8 Number 3 (March)

http://doi.org/10.9770/jesi.2021.8.3(19)

Make your research more visible, join the Twitter account of ENTREPRENEURSHIP AND SUSTAINABILITY ISSUES: @Entrepr69728810

positive attitudes towards remote psychotherapy, although doctors express doubts about making an accurate diagnosis (Berger, 2017; Connolly et al., 2020). In addition, it is noted that application of the methods of remote psychotherapy can be limited by the lack of legal provisions in this area (Bojdani et al., 2020).

\section{Research methodology}

The activities of psychologists in Lithuania are insufficiently regulated by law - the Law on the Practical Activities of Psychologists is still awaiting approval by the Parliament of the Republic of Lithuania. To assess the situation concerning provision of psychological support to most vulnerable persons under the conditions of the COVID-19 pandemic, 240 psychologists were interviewed. With reference to the data of the Ministry of Education and Science (MES), over the 2015-2016 academic year, Lithuanian schools had 753 working psychologists and 47 psychologist assistants, and 164 psychologists worked in pedagogical-psychological services. Based on the data of the Ministry of Health (MH), stamp numbers of a health care specialist were issued to 579 medical psychologists, but in 2015 only 286 psychologists worked in the institutions subordinated to the MH. At the beginning of 2016, 230 psychologists worked in the institutions subordinated to the Ministry of Social Security and Labour (MSSL) (Lithuanian Psychological Association, 2020).

When estimating the size of the sample, it was presumed that the number of psychologists in Lithuania amounts to 2059 people. To ensure a 5\% error rate, approximately 324 respondents had to be surveyed (Internet survey system calculator, available at the address http://www.surveysystem.com/sscalc.htm, was engaged). Since 240 of the respondents were available for the survey, the error rate increased by $5.95 \%$. The survey was being conducted during the period of September-October 2020, following the principles of the "snowball" data collection method. It was established (Duncan, White, \& Nicholson, 2003; Vershinina \& Rodionova, 2011) that when conducting the surveys of hidden populations, the basic problems faced by researchers cover accessibility of the target population and the size of the survey sample.

Respondents. By employing an online survey, the information was obtained from 240 respondents psychologists: 229 female and 11 male. Distribution of the respondents by the pre-formed age groups was uneven: the respondents aged 18-29 accounted for 13.3 percent, the respondents aged 30-49- for 63.3 percent, and the respondents aged 55-65 - for 22.5 percent of the total number, and only 2 respondents were older than 65 . Territorial distribution of the respondents is depicted in Table 1 which indicates that basically the whole territory of Lithuania was covered, although some questionnaires were filled not from Lithuanian cities (apparently by those staying in other European countries, but having contacts with Lithuania and Lithuanian Psychological Association through which the questionnaire was distributed). It can be seen that the majority of the respondents were from Vilnius (41.9 percent of the total sample size). The second largest group of the respondents were from Kaunas (18.4 percent) and Klaipeda (7.3 percent). The respondents from smaller cities, districts or towns accounted for 39.7 percent of the total sample size.

Questionnaire. The questionnaire (26 questions in total) was prepared including the subject questions focused on the psychologists' activities, opinions and suggestions. Most of the questions were close-ended, four questions completely open, and three questions - mixed (several close-ended questions with the last alternative "other", where a respondent could add his / her personal insights). Thus, the questionnaire included seven questions where a respondent was free to express personal views. These answers will be analysed in the further section of this article. A block of the questions on the potential impact of the pandemic and pandemic-related restrictions on population's mental health was presented in the form of seven sub-scales: stress, anxiety, depression, sleep disorders, persistent tiredness, boredom and anger (aggression). The Cronbach's alpha (reliability indicator) of the 
ENTREPRENEURSHIP AND SUSTAINABILITY ISSUES

ISSN 2345-0282 (online) http://jssidoi.org/jesi/

2021 Volume 8 Number 3 (March)

http://doi.org/10.9770/jesi.2021.8.3(19)

Make your research more visible, join the Twitter account of ENTREPRENEURSHIP AND SUSTAINABILITY ISSUES: @Entrepr69728810

aggregate of these sub-scales is extremely high -0.89 , which indicates a strong internal consistency of the answers.

Data processing. Statistical analysis of the data was conducted by using the SPSS-26 software package: the analysis revealed answer frequencies, the relationships between particular variables (Spearman correlation coefficients) as well as means and answer averages (see section of the Results).

\section{Empirical results of the research}

\subsection{Psychologists' attitudes to deviations in population's mental well-being under the conditions of the pandemic}

To assess the real impact of the pandemic or any other crisis on population's mental health, the target population affected by the crisis needs to be surveyed or objective criteria (e.g. frequency of referrals to mental health professionals, statistics of mental disorders) need to be identified. With this study, we aim to assess the possible effects of the COVID-19 pandemic on deviations in population's mental well-being through the attitudes of the professionals who provide psychological services. Nearly all questions in the questionnaire measure experts' attitudes to various aspects of population's mental well-being and psychological service provision.

The central question was formulated as follows: Psychological studies on the effects of the COVID-19 pandemic indicate that disorders such as constant stress, anxiety, depression, sleep disorders, boredom, etc. are most commonly reported. Do you think that the fear of falling ill, loss of employment or income, quarantine-related restrictions on daily life and professional activities really lead to the deviations in population's mental well-being listed below? Then seven determinants indicating the deviations in population's mental well-being were listed (stress, anxiety, depression, sleep disorders, persistent tiredness, boredom and anger / aggression); plausible fluctuations in these determinants under the conditions of the pandemic were evaluated by psychologists on a 6grade scale (from Definitely no to Definitely yes). Mean values of the evaluations provided by the total sample of 240 respondents are depicted in Figure 1.

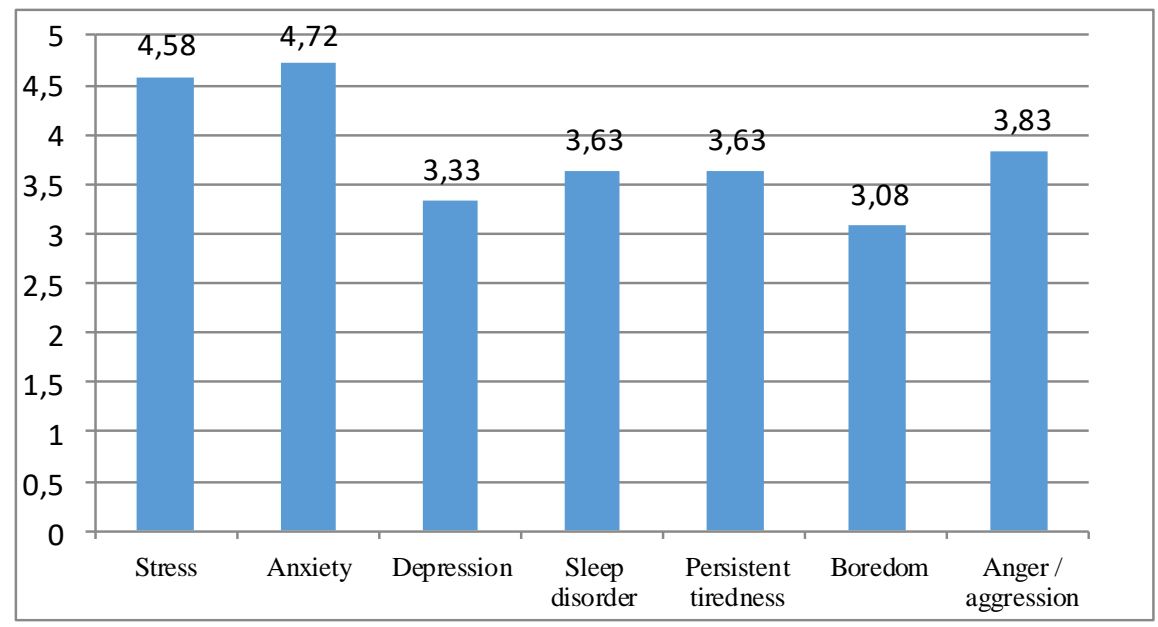

Fig. 1. Mean values of the evaluations regarding the impact of the COVID-19 pandemic on population's mental well-being provided by the total sample of the respondents $(n=240)$ (maximum grade -6$)$. 
Make your research more visible, join the Twitter account of ENTREPRENEURSHIP AND SUSTAINABILITY ISSUES: @Entrepr69728810

Mean values in Figure 1 indicate that positive response rates are higher for plausible fluctuations in population's stress and depression. The COVID-19 pandemic weakly affects population's boredom, although this issue is widely discussed in the public sphere.

\subsection{Assessment of psychological services}

Distribution of the respondents' answers to the question "Has, in your opinion, the need for psychological (psychiatrist) services in the society or community close to you changed during the pandemic?" are depicted in Figure 2. Only 10 percent of the respondents believe that the need for psychological services has remained the same, while others think it has increased to a greater or lesser extent.

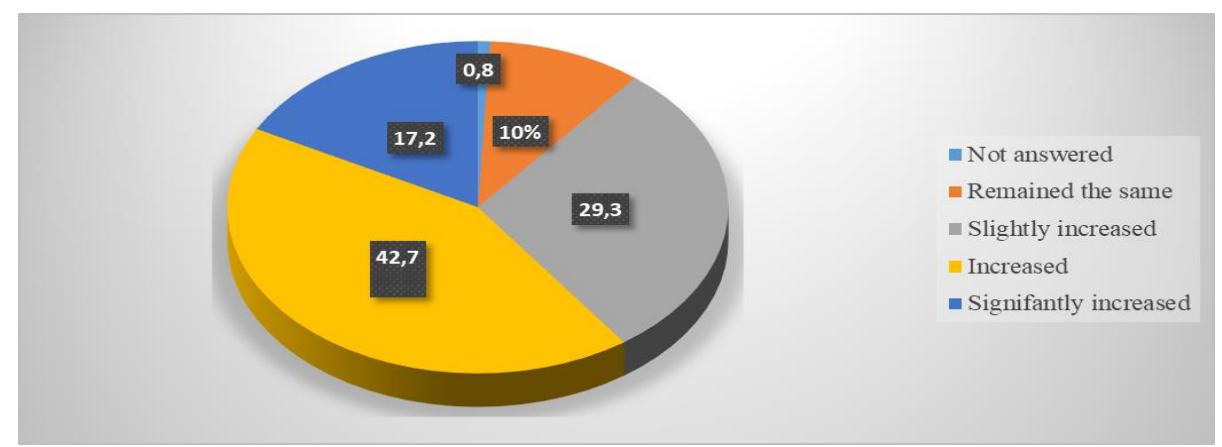

Fig. 2. Has the need for psychological services changed during the pandemic? Respondent answers, percent (compiled by the authors)

The question "How do you assess availability of psychological services in Lithuania in general?" is characterized by a wide range of possible answers (see Fig. 3). The respondents could mark several answer alternatives. Naturally, no service provider marked the answer They are not needed or They are in excess. 40.8 percent of the respondents believe that they are available, but 67 percent marked the answer Poor state support in the area of psychological services; nearly 30 percent of the respondents selected the answer They are accidental, poorly organised.

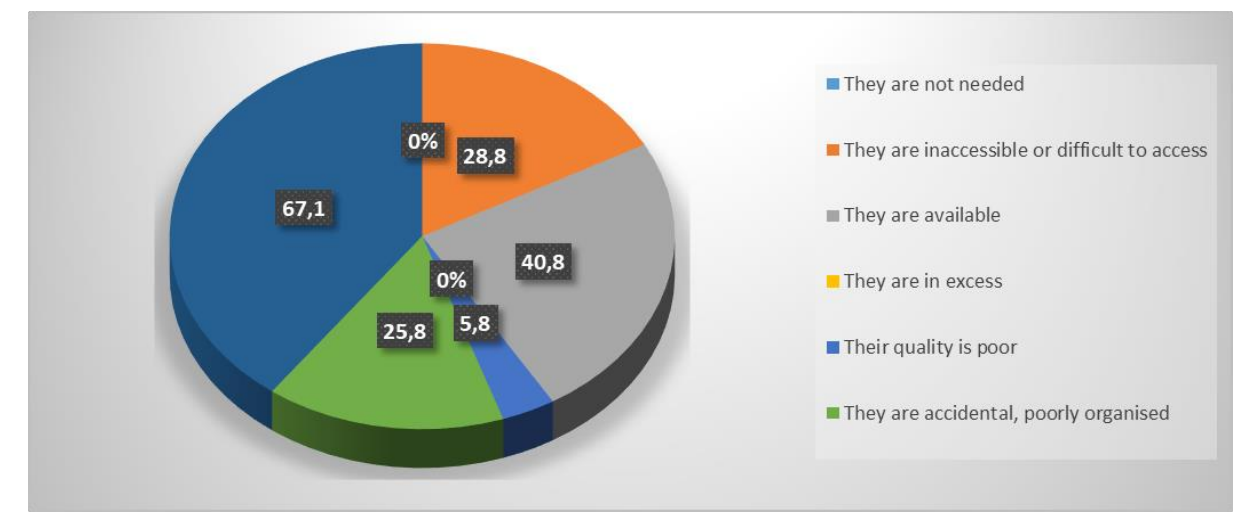

Fig. 3. Respondents' answers regarding (un)availability of psychological services, percent (compiled by the authors)

Several answers could also be marked when answering the question "Does you experience of the COVID-19 pandemic suggest that provision of psychological services should change?" Most frequent choices were as follows (see Fig. 4): service accessibility should be increased, service provision should be organized optimally, networks for remote service provision should be developed, and the answer More significant state support to 
ENTREPRENEURSHIP AND SUSTAINABILITY ISSUES

ISSN 2345-0282 (online) http://jssidoi.org/jesi/

2021 Volume 8 Number 3 (March)

http://doi.org/10.9770/jesi.2021.8.3(19)

Make your research more visible, join the Twitter account of ENTREPRENEURSHIP AND SUSTAINABILITY ISSUES: @Entrepr69728810

cover the costs of the service is appropriate was indicated by 70.8 percent of the respondents. 9 out of 240 marked the answer Other. These respondents emphasized the problems of lack of the facilities for consultations, public education and information, discriminatory attitudes towards psychology specialisations when selecting a workplace (e.g. the restriction applied to educational psychology professionals to work in health care institutions, while clinical or health psychologists are allowed to work in educational institutions). Emphasis was also placed on the low salary of psychologists (especially those working in educational institutions).

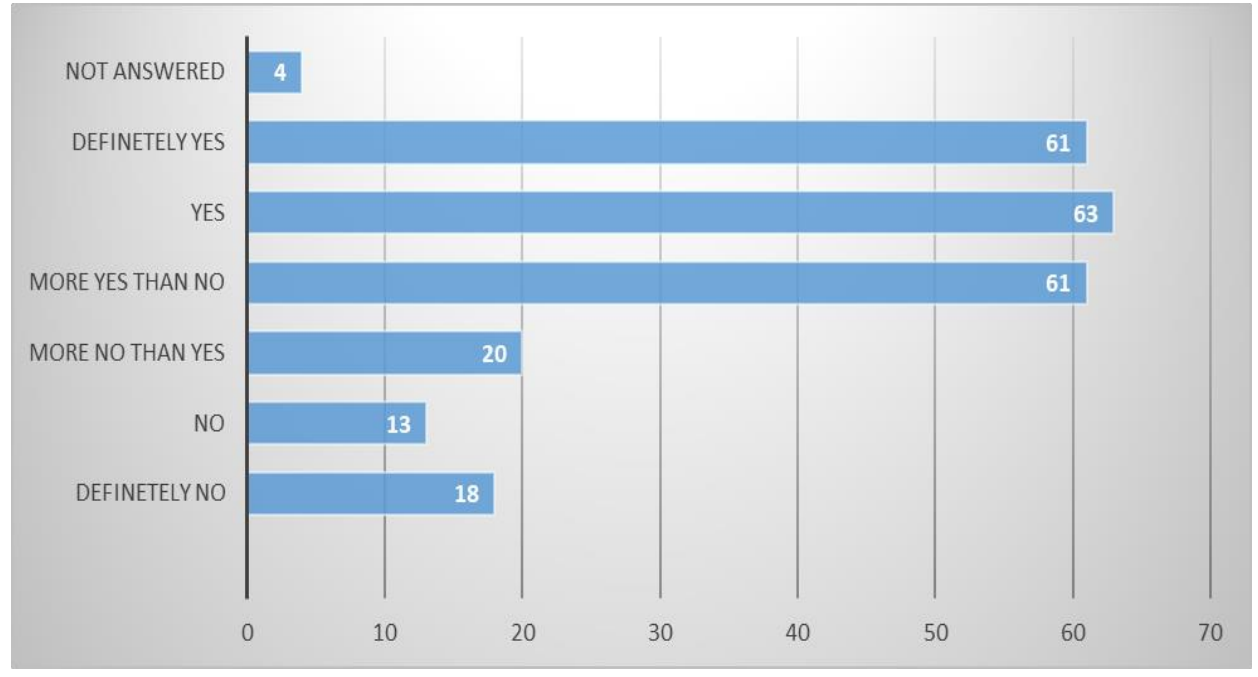

Fig. 4. Distribution of the respondents' answers to the question "Should provision of psychological services change?", persons (compiled by the authors)

Lithuania does not have any legal document regulating psychologists' practical activities. Even the list of the professions under regulation includes only a school psychologist (although professionals of this specialisation have not been and are not prepared in Lithuania). Psychological services are regulated at the knowledge level. They are best organized in the educational system, and a year ago were started in health care institutions (e.g. a psychologist's medical norm was developed). Many European countries have so-called Psychology laws. Lithuania started considering such laws after restoration of the country's independence, but they have not still been approved (mainly due to the differences in psychologists' attitudes), although at least two different bills are under consideration. Therefore, it was expedient to survey the respondents (not only Lithuanian Psychological Association (further LPA) activists or their opponents, but also ordinary LPA's members or professionals that do not belong to this organization) to find out their opinions on this issue.

The respondents were asked the following question: Legal regulation of psychological services varies from one department to another, and there is no unified document regulating psychologists' practical activities. The bill of "A psychologist's practical activity law" is still under consideration. Do you think such a law is necessary? Nearly 20 percent of the respondents (see Table 2) provided the negative answers, but about 77 percent of the respondents more or less support issuing the above-mentioned law (25.4 percent of the respondents provided the answer Definitely yes). 
ENTREPRENEURSHIP AND SUSTAINABILITY ISSUES

ISSN 2345-0282 (online) http://jssidoi.org/jesi/

2021 Volume 8 Number 3 (March)

http://doi.org/10.9770/jesi.2021.8.3(19)

Make your research more visible, join the Twitter account of ENTREPRENEURSHIP AND SUSTAINABILITY ISSUES: @Entrepr69728810

Table 2. Distribution of the respondents' answers regarding the (un)necessity of "A psychologist's practical activity law"

\begin{tabular}{|l|l|l|}
\hline Answers & $\mathrm{n}$ & percentage \\
\hline Did not answer & 4 & 1.7 \\
\hline Definitely not & 18 & 7.5 \\
\hline No & 13 & 5.4 \\
\hline More no than yes & 20 & 8.3 \\
\hline More yes than no & $\mathbf{6 1}$ & $\mathbf{2 5 . 4}$ \\
\hline Yes & $\mathbf{6 3}$ & $\mathbf{2 6 . 3}$ \\
\hline Definitely yes & $\mathbf{6 1}$ & $\mathbf{2 5 . 4}$ \\
\hline
\end{tabular}

Low salaries of psychologists as well as low prices of psychological services are often discussed in the public sphere. For the surveyed sample of the psychologists, the following question was formulated: "In your opinion, are the prices of psychological services in the public sector (in schools, services, health care institutions, etc.) adequate (e.g. compared to the prices charged for other services or salaries paid to other professionals)?" Not surprisingly, 90 percent of the respondents indicated that the prices charged for psychological services are inadequate, i.e. much lower than the prices of other services, and only 9 percent of the respondents would agree that the prices are adequate (see Table 3 ).

Table 3. Distribution of the respondents' answers regarding (in)adequacy of the prices charged for psychological services

\begin{tabular}{|l|l|l|}
\hline Answers & $n$ & Percentage \\
\hline Did not answer & 2 & .8 \\
\hline Definitely not & 140 & 58.3 \\
\hline No & 52 & 21.7 \\
\hline More no than yes & 24 & 10.0 \\
\hline More yes than no & 12 & 5.0 \\
\hline Yes & 7 & 2.9 \\
\hline Definitely yes & 3 & 1.3 \\
\hline
\end{tabular}

\subsection{Recipients of psychological services}

The respondents were asked two questions about the potential recipients of psychological services: with one question, they were asked to indicate which population groups are most in need of psychological assistance in the event of the pandemic; with the second question, the respondents were asked which professionals are most in need of psychological assistance in the event of the pandemic. A huge variety of responses were received. The answers to the first question can be categorized as follows:

1. Age groups (seniors, adolescents and young people, students, middle-aged people);

2. Social status groups (public servants, small entrepreneurs, medical staff, educators, redundant workers, travel agents);

3. Marital status groups (single people, widowed, parents with children);

4. Problematic employment groups (unemployed, isolated, those who have lost their jobs due to the pandemic);

5. Problematic health groups (people with mental or emotional disorders, people with COVID-19, disabled, people who have addicts in their domestic environment, patients and their relatives);

6. Others (those experiencing domestic violence). 


\section{ENTREPRENEURSHIP AND SUSTAINABILITY ISSUES}

ISSN 2345-0282 (online) http://jssidoi.org/jesi/

2021 Volume 8 Number 3 (March)

http://doi.org/10.9770/jesi.2021.8.3(19)

Make your research more visible, join the Twitter account of ENTREPRENEURSHIP AND SUSTAINABILITY ISSUES: @Entrepr69728810

When answering the second question, many respondents indicated medical staff, followed by educators (school and kindergarten teachers) and police officers. Other professionals (municipal administration employees, employment service specialists, salespeople, musicians, sportsmen, psychologists, company managers, private business employees, artists, waiters, hairdressers, maids, event planners) were less commonly mentioned.

\subsection{Determinants of the attitudes to the changes in population's mental well-being}

In this case, the term determinants is not used in full compliance with the strict requirements of the research methodology. The respondents were grouped depending on their answer selections which are treated as independent variables. The analysis comprised four variables: respondents' age, change in the personal psychological well-being during the pandemic, assessment of the need for psychological services and specialization (only the means of the two largest specialization groups - clinical and educational psychology were compared). Evaluation means representing the changes in population's mental well-being (stress, anxiety, etc.) during the pandemic were treated as dependent variables. The professionals in educational psychology are likely to treat the changes in population's mental well-being more seriously, but this tendency is statistically insignificant) Some tendencies to differently assess the effects of the pandemic represented by the independent variables can also be observed overload the report on the research results with insignificant information, we did not include any differences in the values of statistical significance. Only a few cases described below were found to be statistically significant.

First tendency: younger respondents tend to indicate that the pandemic has had stronger effects on population's mental well-being, although statistically significant differences were found only for sleep disorder evaluations (respondents aged 18-29 and 50-65 ( $\mathrm{p} \leq 0.02)$, and respondents aged 18-29 and 30-49 ( $\mathrm{p} \leq 0.05)$.

Second tendency: the respondents who treated their mental well-being as worse, provided higher evaluations to all seven aspects representing population's mental well-being. A substantial number of statistically significant means were found based on the answers of the respondents who noted that well-being remained the same, and based on the answers of the respondents who indicated that well-being significantly worsened due to: stress $(\mathrm{p} \leq 0.03)$, anxiety $(\mathrm{p} \leq 0.00)$, depression $(\mathrm{p} \leq 0.01)$, sleep disorders $(\mathrm{p} \leq 0.05)$, tiredness $(\mathrm{p} \leq 0.00)$. Three statistically significant differences were found based on the answers on the respondents who noted that well-being slightly worsened or significantly worsened due to: anxiety $(\mathrm{p} \leq 0.05)$, depression $(\mathrm{p} \leq 0.05)$ and persistent tiredness $(\mathrm{p} \leq 0.05)$.

Third tendency: the respondents who envisage a greater need for psychological services tend to treat plausible changes in population's mental well-being as more significant (see Table 11). The statistically significant differences in the mean values were found when processing the answers remained the same and significantly increased due to: stress $(p \leq 0.01)$, sleep disorders $(p \leq 0.02)$ and tiredness $(p \leq 0.00)$. Four more statistically significant differences were found when processing the evaluations of stress and tiredness provided by other respondent groups. The direction, however, persists the same: a greater need for psychological services is envisaged, a greater emphasis is placed on plausible changes in population's mental well-being.

\subsection{Correlations between the variables under consideration}

Because the values of the variables were not dichotomous, but expressed as evaluation scales (from 4 to 6 evaluations), Pearson correlation coefficient was employed. The tendencies depicted in Tables 1 and 2 are also confirmed by the correlations between the main variables. Strong correlations were found between the seven indicators of population's mental well-being evaluated by the respondents (values $r$ range from 0.45 to nearly 


\section{ENTREPRENEURSHIP AND SUSTAINABILITY ISSUES}

ISSN 2345-0282 (online) http://jssidoi.org/jesi/

2021 Volume 8 Number 3 (March)

http://doi.org/10.9770/jesi.2021.8.3(19)

Make your research more visible, join the Twitter account of ENTREPRENEURSHIP AND SUSTAINABILITY ISSUES: @Entrepr69728810

0.7). Given that the number of the respondents amounts to 240 , the correlations observed between the indicators are very strong, as evidenced by the high Cronbach's alpha estimated for the seven scales under consideration, mentioned in Section 2.1. These correlations reflect a simple respondent evaluation tendency: a respondent, who provides a higher evaluation to one of the factors representing the changes in population's mental well-being, is likely to provide a higher evaluation to any other factor. Relatively strong correlations were found between the answers to the question Have you undergone the changes in your psychological well-being?, and the answers to the other questions (9 statistically significant correlations out of 11). Six statistically significant correlations out of 11 were observed between the answers to the question Have you had to provide psychological assistance during the pandemic? and the answers to the other questions. A substantial number of the statistically significant correlations were observed between the answers to the question regarding the changes in the need for psychological services and the other variables.

\section{Conclusions and recommendations}

Literature analysis and survey results revealed that psychological well-being of Lithuanian population and entrepreneurs, according to psychologists, shows signs of worsening not only due to uncertainty about how long the pandemic will last, but also due to deteriorating living conditions (exclusion, business closures, mass bankruptcies). The state must ensure that the health of its citizens, including mental health, is not harmed. Thus, based on the research results, it can be stated that to improve the provision of psychological services in transition economies under the extreme conditions, it is necessary to:

1) balance workloads and professionals' salaries (raise the number of workplaces in schools; raise the number of workplaces in medical institutions; raise salaries/reestimate payment coefficients);

2) provide training for psychologists (on how to ensure crisis assistance, arrange remote counselling; remote training and competence building sessions should also be arranged);

3) inform population about the services available (disseminate the information to the public on where counselling is available; cover private counselling costs from the state's budget; ensure that all age groups are informed about the services provided not only thought the mobile apps and internet websites, but also by involving doctors and nurses who can provide the guidance on who patients can turn to when they are seeking assistance; employ a separate telephone line for providing the information about psychological assistance);

4) eliminate organisational problems (ensure decent work conditions not only in terms of the remote work in the crisis situation, but also in terms of providing psychologists with offices, equipment, personal protective measures and rest areas; enhance cooperation among medical institutions, schools and other health care institutions; build mobile crisis teams (crisis management teams) that could ensure communication with other professionals and provide comprehensive consultations). Currently, there is a lack of a unified strategy and specific guidelines on how the services can be provided. The status of psychologists should be equalized with the status of the professionals working in the mental health system.

\section{References}

Andersson, G. (2016). Internet-delivered psychological treatments. Annual Review of Clinical Psychology, 12, 157-179. https://doi.org/10.1146/annurev-clinpsy-021815-093006

Berger, T. (2017). The therapeutic alliance in internet interventions: a narrative review and suggestions for future research. Psychotherapy Research, 27, 511-524. https://doi.org/10.1080/10503307.2015.1119908 


\section{ENTREPRENEURSHIP AND SUSTAINABILITY ISSUES}

ISSN 2345-0282 (online) http://jssidoi.org/jesi/

2021 Volume 8 Number 3 (March)

http://doi.org/10.9770/jesi.2021.8.3(19)

Make your research more visible, join the Twitter account of ENTREPRENEURSHIP AND SUSTAINABILITY ISSUES: @Entrepr69728810

Besenyő, J., Kármán, M. (2020). Effects of COVID-19 pandemy on African health, political and economic strategy. Insights into Regional Development, 2(3), 630-644. https://doi.org/10.9770/IRD.2020.2.3(2)

Bojdani, E., Rjagopalan, A., Chen, A., Gearin, P., Olcott, W., Shankar, V., Cloutier, A., Solomon, H., Naqvi, N. Z., Batty, N., Festin, F. E. D., Tahera, D., Chang, G., DeLisi, L. E. (2020). COVID-19 pandemic: impact on psychiatric care in the United States. Psychiatry Research, 289, 113069. https://doi.org/10.1016/j.psychres.2020.113069

Chen, Q., Liang, M., Li, Y., Guo, J., Fei, D., Wang, L., He, L., Sheng, C., Cai, Y., Li, X., Wang, J., Zhang, Z. (2020). Mental health care for medical staff in China during the COVID-19 outbreak. Lancet Psychiatry, 7(4), e15-e16. https://doi.org/10.1016/S2215$\underline{0366(20) 30078-X}$

Connolly, S. L., Miller, C. J., Lindsay, J. A., Bauer, M. S. (2020). A systematic review of providers' attitudes toward telemental health via videoconferencing. Clinical Psychology Science and Practice, 27(2), e12311. https://doi.org/10.1111/cpsp.12311

Dong, L., Bouey, J. (2020). Public Mental Health Crisis during COVID-19 Pandemic, China. Emerging Infectious Diseases, 26(7), 16161618. https://doi.org/10.3201/eid2607.202407

Duan, L., Zhu, G. (2020). Psychological interventions for people affected by the COVID-19 epidemic. Lancet Psychiatry, 7(4), 300-302. https://doi.org/10.1016/S2215-0366(20)30073-0

Duncan, D. F., White, J. B. and Nicholson, T. (2003). Using internet based surveys to reach hidden populations: case of non-abusive illicit drug users. American Journal of Health Behaviour, 27(3), 208-18.

He, Z., Chen, J., Pan, K., Yue, Y., Cheung, T., Yuan, Y., Du, N., Zhao, Y., Feng, Y., Zhou, D., Zhou Y., Lu, F., Chen, Y., He, M., Xiang, Y. T. (2020). The development of the Covid-19 psychological resilience model and its efficacy during the Covid-19 pandemic in China. International Journal of Biological Sciences, 16(15), 2828-2834. https://doi.org/10.7150/ijbs.50127

Humer, E., Pieh, C., Kuska, M., Barke, A., Doering, B. K., Gossmann, K., Trnka, R., Meier, Z., Kascakova, N., Tavel, P., Probst, T. (2020). Provision of Psychotherapy during the COVID-19 Pandemic among Czech, German and Slovak Psychotherapists. International Journal of Environmental Research and Public Health, 17(13), p. 4811. https://doi.org/10.3390/ijerph17134811

Inchausti, F., MacBeth, A., Hasson-Ohayon, I., Dimaggio, G. (2020). Psychological Intervention and COVID-19: What We Know So Far and What We Can Do. Journal of Contemporary Psychotherapy, 27, 1-8. https://doi.org/10.1007/s10879-020-09460-w

Jiang, X., Deng, L., Zhu, Y., Ji, H., Tao, L., Liu, L., Yang, D., Ji, W. (2020). Psychological crisis intervention during the outbreak period of new coronavirus pneumonia from experience in Shanghai. Psychiatry Research, 286. https://doi.org/10.1016/j.psychres.2020.112903

Koushik N. S. (2020). A Population Mental Health Perspective on the Impact of COVID-19. Psychological Trauma: Theory, Research, Practice, and Policy, 5(12), 529-530. http://dx.doi.org/10.1037/tra0000737

Lithuanian Psychological Association. (2020) Official statistics on psychologists working in Lithuania. Retrieved from: http://www.psichologusajunga.lt/index.php?p=607\&lng=lt

Marazziti, D., Pozza A., Giusepe M., Conversano C. (2020). The Psychosocial Impact of COVID-19 Pandemic in Italy: A Lesson for Mental Health Prevention in the First Severely hit European Country. Psychological Trauma: Theory, Research, Practice, and Policy, 5(12), 531-533. http://dx.doi.org/10.1037/tra0000687

Mohammed, A., Sheikh, T. L., Poggensee, G., Nguku, P. Olayinka, A., Ohuabunwo, C., Eaton, J. (2015). Mental health in emergency response: lessons from Ebola. The Lancet, 2(11), p. 955-957. http://dx.doi.org/10.1016/S2215-0366(15)00451-4

National Institute for Health and Care Excellence (NICE). (2018). Posttraumatic stress disorder. Retrieved from: https://www.nice.org.uk/guidance/ng116

Orru, G., Ciacchini, R., Gemignani, A., Conversano, C. (2020). Psychological intervention measures during the COVID-19 pandemic. Clinical Neuropsychiatry, 17(2), p. 76-79. http://doi.org/10.36131/CN20200208 


\section{ENTREPRENEURSHIP AND SUSTAINABILITY ISSUES}

ISSN 2345-0282 (online) http://jssidoi.org/jesi/

2021 Volume 8 Number 3 (March)

http://doi.org/10.9770/jesi.2021.8.3(19)

Make your research more visible, join the Twitter account of ENTREPRENEURSHIP AND SUSTAINABILITY ISSUES: @Entrepr69728810

Pfefferbaum, B., North, C. C. (2020). Mental Health and the Covid-19 Pandemic. The New England Journal of Medicine, 383(6), p. 510513. https://www.nejm.org/doi/pdf/10.1056/NEJMp2008017? articleTools=true

Shulman, M., John, M., Kane, J. M. (2017). Home-based outpatient telepsychiatry to improve adherence with treatment appointments: a pilot study. Psychiatric Services, 68(7), 743-746. http://doi.org/10.1176/appi.ps.201600244

Thomas, J. F., Novins, D. K., Hosokawa, P. W., Olson, C. A., Hunter, D., Brent, A. S., Frunzi, G., Libby, A. M. (2018). The Use of telepsychiatry to provide cost-efficient care during paediatric mental health emergencies. Psychiatric Services, 69(2), 161-168. http://doi.org/10.1176/appi.ps.201700140

Vershinina, N., Rodionova, Y. (2011). Methodological issues in studying hidden populations operating in informal economy. International Journal of Sociology and Social Policy, 31(11/12), 697-716

Vizheh, M., Qorbani, M., Arzaghi, S. M., Muhidin, S., Javanmard, Z., Esmaeili, M. (2020). The mental health of healthcare workers in the COVID-19 pandemic: a systematic review. Journal of Diabetes and Metabolic Disorders, 26, 1-12. http://doi.org/10.1007/s40200-020$\underline{00643-9}$

World Health Organisation. (2020). Setup and management of COVID-19 hotlines. Retrieved from: https://apps.who.int/iris/bitstream/handle/10665/336027/WHO-EURO-2020-1206-40956-55530-eng.pdf

Xiao, H., Zhang, Y., Kong, D., Li, S., Yang, N. (2020). The Effects of Social Support on Sleep Quality of Medical Staff Treating Patients with Coronavirus Disease 2019 (COVID-19) in January and February 2020 in China. Medical Science Monitor, 26. http://doi.org/10.12659/MSM.923549

Zhou, X. (2020). Psychological crisis interventions in Sichuan Province during the 2019 novel coronavirus outbreak. Psychiatry Research, 286. http://doi.org/10.1016/j.psychres.2020.112895

Prof. dr. Tomas DAVULIS is a Dean of Law Faculty, Vilnius University, the leader of the national project COVID 19. Research interests: European Union and International Labour Law, Labour Market, Collective Labour Relationships, Equality, Social Rights, Social Mode.

ORCID ID: https://orcid.org/0000-0001-5018-140X

Prof. dr. Ligita GASPARÉNIENE் is a Head of Science and Innovation Department, Vilnius University, the leader of the national project "Welfare society". Research interests: shadow economy, digital shadow economy, corruption, money laundering, investments in gold, monetary policy.

ORCID ID: $\underline{\text { https://orcid.org/0000-002-5535-6552 }}$

Evaldas RAISTENSKIS is a junior researcher at Vilnius University, Faculty of Law, Science and Innovation Department, Criminal Law General Science Center. I am currently writing a dissertation work for Criminal Liability for Contraband. Research interests: criminal smuggling, shadow economy, corruption.

ORCID ID: https://orcid.org/0000-0003-3049-2926

Copyright (C) 2021 by author(s) and VsI Entrepreneurship and Sustainability Center

This work is licensed under the Creative Commons Attribution International License (CC BY).

http://creativecommons.org/licenses/by/4.0/

CC) (i) Open Access 